\title{
AKTIVITAS EKSTRAK ETANOL KULIT BUAH JENGKOL (Pithecellobium jiringa (Jack) Prain.) SEBAGAI BIOHERBISIDA GULMA BAYAM DURI (Amaranthus spinosus L.) DAN RUMPUT PAITAN (Paspalum conjugatum Berg.)
}

\author{
Siti Nur Hasanah ${ }^{1}$, Elvi Rusmiyanto $\mathbf{P W}^{\mathbf{1}}$, Mukarlina ${ }^{1}$ \\ ${ }^{1}$ Program Studi Biologi, Fakultas MIPA, Universitas Tanjungpura, Jl. Prof. Dr. H. Hadari Nawawi, Pontianak \\ Email korespondensi: sitinurhasanah270796@gmail.com
}

\begin{abstract}
Weed is a plant that grow in undesirable places, especially in the location of cultivated plants. Alelochemical use as bioherbicide is one of the ways in weed control and is safe for the environment. The study was conducted to test the potential of $P$. jiring $a$ fruit peel extract as bioherbicide on the germination and growth of $A$ spinosus and P.conjugatum weeds. The study used a completely randomized design (RAL) with the concentration of extract $(\mathrm{P})$ used consisting of 6 treatments, namely $\mathrm{P} 1=0$ (control), $\mathrm{P} 2=0.1 ; \mathrm{P} 3=0.2 ; \mathrm{P} 4=$ 0.3 ; $\mathrm{P} 5=0.4$; and $\mathrm{P} 6=0.5 \mathrm{~g} / \mathrm{ml}$. each treatment was repeated 5 times. The results of the study showed that the concentration extract of $0.5 \mathrm{~g} / \mathrm{ml}$ was an inverse concentration to inhibit the weed seeds germination of A.spinosus and $P$. conjugatum. Good concentration extract to inhibit growth $A$. spinosus and $P$. conjugatum is $0.3 \mathrm{~g} / \mathrm{ml}$ which results in inhibition of plant height, root length, wet weight and dry weight. Based on research conducted on fruit peel extract $P$. jiring $a$ has the potential as a bioherbicide.
\end{abstract}

Keywords : Bioherbicide, A.spinosus, $P$. conjugatum, $P$. jiringa

\section{PENDAHULUAN}

Gulma merupakan tumbuhan yang tumbuh di tempat yang tidak dikehendaki, terutama di lokasi tanaman budidaya. Keberadaan gulma pada areal tanaman budidaya dapat menimbulkan kerugian baik dari segi kuantitas maupun kualitas produksi (Junaedi dkk., 2006). Gulma yang banyak tumbuh pada lahan tanaman budidaya diantaranya bayam duri (Amaranthus spinosus L.) dan rumput paitan (Paspalum conjugatum Berg.).

Gulma A. spinosus merupakan tumbuhan pengganggu yang banyak ditemukan pada areal budidaya tanaman jagung dan kacangkacangan. A. spinosus merupakan gulma berdaun lebar, sangat toleran terhadap perubahan iklim, banyak tumbuh di dataran rendah hingga menengah. A. spinosus merupakan gulma dominan ketiga di dunia yang memiliki pertumbuhan cepat di daerah tropis. (Ronald dan Smith, 2000). P. conjugatum merupakan gulma berdaun sempit, memiliki daya toleransi yang baik terhadap faktor lingkungan di sekitar, $P$. conjugatum merupakan gulma yang banyak ditemukan di perkebunan sawit dan karet. (Isda dkk., 2013).
Pengendalian gulma dengan menggunakan herbisida sintetis merupakan metode yang paling banyak digunakan petani sebagai penghambat pertumbuhan dan perkembangan berbagai jenis gulma. Penggunaan herbisida sintetik dapat menimbulkan berbagai masalah, antara lain pencemaran lingkungan, penurunan kadar organik tanah dan gulma menjadi toleran terhadap jenis herbisida tertentu (Senjaya dan Surakusumah, 2007; Duke dan Lydon, 1993).

Kulit Jengkol (Pithecellobium jiringa) selama ini tergolong limbah organik yang tidak memberikan nilai ekonomis. Hasil penelitian Rahayu (2001) menyatakan kulit jengkol mengandung senyawa kimia diantaranya alkaloid, steroid/triterpenoid, saponin, flavonoid dan tanin. Penelitian Delsi (2010), menyatakan bahwa ekstrak kulit jengkol konsentrasi $10 \%$ dapat meningkatkan pertumbuhan tanaman padi, dan menurukan viabilitas serta vigor gulma. Informasi penggunaan senyawa alelokimia sebagai bioherbisida pada $P$. jiringa dalam menghambat pertumbuhan gulma belum banyak dilaporkan. Oleh karena itu, maka penelitian tentang potensi ekstrak $P$. jiringa sebagai 
bioherbisida pengendali gulma A.spinosus dan P.conjugatum perlu dilakukan.

\section{BAHAN DAN METODE}

\section{Waktu dan Tempat Penelitian}

Penelitian dilakukan selama 4 bulan yaitu dari bulan April-Juli 2018. Penelitian uji perkecambahan dan pertumbuhan dilakukan di Laboratorium dan Rumah Kasa Jurusan Biologi Fakultas Matematika dan Ilmu Pengetahuan Alam Universitas Tanjungpura Pontianak. Analisis tanah dilakukan di Laboratorium Kimia dan Kesuburan Tanah Fakultas Pertanian Universitas Tanjungpura Pontianak. Evaporasi maserat dilakukan di Laboratorium Biokimia Politeknik Negeri

Pontianak.

\section{Bahan}

Bahan-bahan yang digunakan adalah kulit buah $P$. jiringa, etanol, tanah gambut, biji gulma $P$. conjugatum dan A. spinosus.

\section{Metode Penelitian}

Penelitian ini menggunakan Rancangan Acak Lengkap (RAL) dengan konsentrasi ekstrak $(\mathrm{P})$ yang digunakan terdiri dari 6 perlakuan, yaitu $\mathrm{P}_{1}=0$ (kontrol), $\mathrm{P}_{2}=0,1 ; \mathrm{P}_{3}=0,2 ; \mathrm{P}_{4}=0,3 ; \mathrm{P}_{5}=0,4$ dan $\mathrm{P}_{6}=0,5$ $\mathrm{g} / \mathrm{ml}$. Masing-masing perlakuan diulang sebanyak 5 kali sehingga diperoleh 30 unit percobaan untuk masing-masing gulma.

\section{Prosedur Kerja}

\section{Pengambilan Sampel}

Kulit buah jengkol yang digunakan sebanyak $10 \mathrm{~kg}$ berat basah. Biji gulma P.conjugatum dan A.spinosus yang digunakan yaitu dari buah yang berwarna coklat.

\section{Ekstraksi Kulit Buah P. jiringa}

Sampel kulit buah jengkol yang telah disiapkan dicuci bersih dan dikering anginkan selama 5 hari. Sampel yang sudah kering kemudian dihaluskan dengan $d r y$ blender sehingga didapatkan serbuk sebanyak $1 \mathrm{~kg}$. Setelah dimaserasi dengan pelarut etanol teknis selama 4x24 jam dan disimpan di dalam toples kaca. Maserat yang diperoleh disaring dan diuapkan dengan vacum rotary evaporator sampai diperoleh ekstrak kental. Ekstrak yang diperoleh disimpan di dalam desikator silika gel.

\section{Perkecambahan Biji}

Biji gulma $P$. conjugatum dan $A$. spinosus sebanyak masing-masing 10 biji disemai pada polybag, biji disemprot dengan $10 \mathrm{ml}$ larutan ekstrak sesuai perlakuan pada awal penyemaian. Pengamatan perkecambahan diakhiri pada hari ke-12 (Enni, dkk., 2017).

\section{Pertumbuhan}

Benih gulma sebanyak 3 biji disemai pada setiap polibag. Setelah 12 hari dipilih 1 gulma yang memiliki ukuran tinggi yang sama pada masingmasing polybag. Penyemprotan larutan ekstrak sebanyak $10 \mathrm{ml}$ dilakukan sesuai dengan perlakuan yang diberikan pada hari ke-12 dan ke22 setelah tanam. Pengamatan dihentikan pada hari ke-32 setelah tanam (Enni dkk., 2017).

\section{Parameter pengamatan}

Parameter perkecambahan biji $A$. spinosus dan $P$. conjugatum yang diamati meliputi persentase perkecambahan $(\%)$ dan panjang kecambah $(\mathrm{cm})$. Parameter pertumbuhan $A$. spinosus dan $P$. conjugatum yang diamati meliputi tinggi tanaman $(\mathrm{cm})$, berat basah $(\mathrm{g})$, dan berat kering $(\mathrm{g})$.

\section{HASIL DAN PEMBAHASAN}

\section{Hasil}

Pengaruh ekstrak kulit P.jiringa terhadap perkecambahan biji gulma $A$. spinosus dan $P$. conjugatum. Hasil rerata persentase perkecambahan dan panjang kecambah gulma $A$. spinosus dan $P$. conjugatum dengan pemberian ekstrak kulit $P$. jiringa dapat dilihat pada Tabel 1 .

Tabel 1 Rerata persentase perkecambahan dan panjang kecambah gulma A.spinosus dan $P$. conjugatum dengan pemberian ekstrak kulit $P$. jiringa.

Gulma A. spinosus Gulma P.conjugatum

\begin{tabular}{ccccc}
\hline $\begin{array}{c}\text { Perlakuan } \\
(\mathrm{g} / \mathrm{ml})\end{array}$ & $\begin{array}{c}\text { Persentase } \\
\text { Perkecam } \\
\text { bahan } \\
(\%)\end{array}$ & $\begin{array}{c}\text { Rerata } \\
\text { Panjang } \\
\text { Kecam } \\
\text { bah } \\
(\mathrm{cm})\end{array}$ & $\begin{array}{c}\text { Persentase } \\
\text { Perkecam } \\
\text { bahan } \\
(\%)\end{array}$ & $\begin{array}{c}\text { Rerata } \\
\text { Panjang } \\
\text { Kecam } \\
\text { bah } \\
(\mathrm{cm})\end{array}$ \\
\hline P0(0) & $100^{\mathrm{a}}$ & $6,76^{\mathrm{a}}$ & $100^{\mathrm{a}}$ & $5,20^{\mathrm{a}}$ \\
P1(0,1) & $62^{\mathrm{b}}$ & $3,71^{\mathrm{b}}$ & $70^{\mathrm{b}}$ & $2,68^{\mathrm{b}}$ \\
P2(0,2) & $54^{\mathrm{b}}$ & $2,68^{\mathrm{c}}$ & $58^{\mathrm{bc}}$ & $2,32^{\mathrm{b}}$ \\
P3(0,3) & $40^{\mathrm{c}}$ & $1,86^{\mathrm{d}}$ & $46^{\mathrm{c}}$ & $1,57^{\mathrm{c}}$ \\
P4(0,4) & $20^{\mathrm{d}}$ & $0,85^{\mathrm{e}}$ & $20^{\mathrm{d}}$ & $0,85^{\mathrm{d}}$ \\
P5(0,5) & $4^{\mathrm{e}}$ & $0,18^{\mathrm{f}}$ & $8^{\mathrm{d}}$ & $0,25^{\mathrm{e}}$ \\
\hline Keterangan
\end{tabular}

Keterangan : Angka-angka pada kolom yang diikuti huruf yang tidak sama menunjukkan pengaruh berbeda nyata menurut uji Duncan pada signifikasi $5 \%$.

Perlakuan ekstrak kulit $P$. jiringa berpengaruh nyata terhadap persentase perkecambahan biji A. spinosus $\left(\mathrm{F}_{5,24}=59,062, \boldsymbol{\square}=0.000\right)$ persentase 
perkecambahan biji gulma $P$. conjugatum $\left(\mathrm{F}_{5,24}=\right.$ $59,404, \boldsymbol{\rho}=0,0000$ ), dan rerata panjang kecambah gulma $A$. spinosus $\left(\mathrm{F}_{5,24}=105,574, \boldsymbol{\rho}=0.000\right)$ rerata panjang kecambah gulma $P$. conjugatum $\left(\mathrm{F}_{5}\right.$, $24=74,823, \boldsymbol{\rho}=0,000 ;$ Duncan $)$.

Berdasarkan hasil uji lanjut Duncan pada persentase perkecambahan dan panjanag kecambah $A$. spinosus dan $P$. conjugataum menunjukkan semua perlakuan berbeda nyata dengan kontrol. Konsentrasi $0,5 \mathrm{~g} / \mathrm{ml}$ merupakan konsentrasi yang mampu menghambat perkecambahan biji gulma $A$. spinosus dan $P$. conjugatum pada persentase perkecambahan masingmasing $4 \%$ dan $8 \%$. Rerata panjang kecambah P1, P2, P3, P4 dan P5 menunjukkan hasil berbeda nyata dengan kontrol. Perlakuan konsentrasi 0,5 g/ml menunjukkan rerata panjang kecambah terendah pada gulma $A$. spinosus dan $P$. conjugataum masingmasing $0,18 \mathrm{~cm}$ dan $0,25 \mathrm{~cm}$ (Tabel 1).

Pengaruh ekstrak kulit $P$. jiringa terhadap pertumbuhan gulma $A$. spinosus dan $P$. conjugatum. Hasil rerata tinggi gulma dan panjang akar gulma A.spinosus dan $P$. conjugatum dengan pemberian ekstrak kulit $P$. jiringa dapat dilihat pada tabel 2 .

Tabel 2 Rerata tinggi gulma dan panjang akar gulma $A$. spinosus dan $P$. conjugatum dengan pemberian ekstrak kulit $P$. jiringa

\begin{tabular}{ccccc}
\hline & \multicolumn{2}{c}{ Gulma A. spinosus } & \multicolumn{2}{c}{$\begin{array}{c}\text { Gulma } \\
\text { P.conjugatum }\end{array}$} \\
\hline $\begin{array}{c}\text { Perlakuan } \\
(\mathrm{g} / \mathrm{ml})\end{array}$ & $\begin{array}{c}\text { Tinggi } \\
\text { Gulma } \\
(\mathrm{cm})\end{array}$ & $\begin{array}{c}\text { Panjang } \\
\text { Akar } \\
(\mathrm{cm})\end{array}$ & $\begin{array}{c}\text { Tinggi } \\
\text { Gulma } \\
(\mathrm{cm})\end{array}$ & $\begin{array}{c}\text { Panjang } \\
\text { akar } \\
(\mathrm{cm})\end{array}$ \\
\hline P0(0) & $30,00^{\mathrm{a}}$ & $24,92^{\mathrm{a}}$ & $13,46^{\mathrm{a}}$ & $12,88^{\mathrm{a}}$ \\
P1(0,1) & $21,32^{\mathrm{b}}$ & $16,00^{\mathrm{b}}$ & $9,02^{\mathrm{b}}$ & $8,60^{\mathrm{a}}$ \\
P2(0,2) & $8,26^{\mathrm{c}}$ & $6,06^{\mathrm{c}}$ & $1,86^{\mathrm{c}}$ & $1,80^{\mathrm{b}}$ \\
P3 $(0,3)$ & $3,42^{\mathrm{c}}$ & $2,74^{\mathrm{c}}$ & $1,20^{\mathrm{c}}$ & $1,20^{\mathrm{b}}$ \\
P4(0,4) & $2,50^{\mathrm{c}}$ & $1,76^{\mathrm{c}}$ & $0,00^{\mathrm{c}}$ & $0,00^{\mathrm{b}}$ \\
P5(0,5) & $0,00^{\mathrm{c}}$ & $0,00^{\mathrm{c}}$ & $0,00^{\mathrm{c}}$ & $0,00^{\mathrm{b}}$ \\
\hline
\end{tabular}

Keterangan : Angkaangka pada kolom yang diikuti huruf yang tidak sama menunjukkan pengaruh berbeda nyata menurut uji Duncan pada signifikasi $5 \%$.

Perlakuan ekstrak kulit $P$. jiringa berpengaruh nyata terhadap tinggi gulma $A$. spinosus $\left(\mathrm{F}_{5,24}=19,764, \rho=\right.$ 0.000 Duncan) tinggi gulma $P$. conjugatum $\left(\mathrm{F}_{5,24}=16,909, \boldsymbol{\rho}=0,000\right)$, panjang akar gulma $A$. spinosus $\left(\mathrm{F}_{5,24}=20,596, \rho=0,000\right.$ Duncan $)$ dan panjang akar $P$. conjugatum $\left(\mathrm{F}_{5,24}=14,954, \rho=0,000\right.$; Duncan).

Uji lanjut Duncan pada parameter tinggi gulma dan panjang akar gulma $A$. spinosus dan $P$. conjugatum konsentrasi ekstrak kulit $P$. jiringa menunjukkan hasil berbeda nyata dengan kontrol (Tabel 2).
Rerata berat basah dan berat kering gulma A.spinosus dan $P$. conjugatum dengan pemberian ekstrak kulit $P$. jiringa.

Hasil rerata berat basah dan berat kering gulma A.spinosus dan $P$. conjugatum dengan pemberian ekstrak kulit $P$. jiringa dapat dilihat pada tabel 3.

Tabel 3 Rerata berat basah dan berat kering gulma A.spinosus dan $P$. conjugatum dengan pemberian ekstrak kulit $P$. jiringa

\begin{tabular}{ccccc}
\hline & \multicolumn{2}{c}{ Gulma A. spinosus } & \multicolumn{2}{c}{ Gulma P.conjugatum } \\
\hline $\begin{array}{c}\text { Perlaku- } \\
\text { an } \\
(\mathrm{g} / \mathrm{ml})\end{array}$ & $\begin{array}{c}\text { Berat } \\
\text { Basah } \\
(\mathrm{g})\end{array}$ & $\begin{array}{c}\text { Berat } \\
\text { Kering } \\
(\mathrm{g})\end{array}$ & $\begin{array}{c}\text { Berat } \\
\text { Basah } \\
(\mathrm{g})\end{array}$ & $\begin{array}{c}\text { Berat } \\
\text { Kering } \\
(\mathrm{g})\end{array}$ \\
\hline $\mathrm{P} 0(0)$ & $6,8075^{\mathrm{a}}$ & $0.0384^{\mathrm{a}}$ & $0,0576^{\mathrm{a}}$ & $0,00054^{\mathrm{a}}$ \\
$\mathrm{P} 1(0,1)$ & $4,7696^{\mathrm{b}}$ & $0,0217^{\mathrm{b}}$ & $0,0228^{\mathrm{b}}$ & $0,00036^{\mathrm{b}}$ \\
$\mathrm{P} 2(0,2)$ & $2,0932^{\mathrm{c}}$ & $0,0049^{\mathrm{c}}$ & $0,0033^{\mathrm{c}}$ & $0,00006^{\mathrm{c}}$ \\
$\mathrm{P} 3(0,3)$ & $0,6843^{\mathrm{cd}}$ & $0,0014^{\mathrm{c}}$ & $0,0018^{\mathrm{c}}$ & $0,00002^{\mathrm{c}}$ \\
$\mathrm{P} 4(0,4)$ & $0,5601^{\text {cd }}$ & $0,0010^{\mathrm{c}}$ & $0,0000^{\mathrm{c}}$ & $0,00000^{\mathrm{c}}$ \\
P5(0,5) & $0,0000^{\mathrm{d}}$ & $0,0000^{\mathrm{c}}$ & $0,0000^{\mathrm{c}}$ & $0,00000^{\mathrm{c}}$ \\
\hline
\end{tabular}

Keterangan : Angka-angka pada kolom yang diikuti huruf yang tidak sama menunjukkan pengaruh berbeda nyata menurut uji Duncan pada signifikasi $5 \%$.

Hasil uji lanjut Duncan pada parameter tinggi gulma dan panjang akar gulma $A$. spinosus dan $P$. conjugatum konsentrasi ekstrak kulit $P$. jiringa menunjukkan hasil berbeda nyata dengan kontrol. Konsentrasi $0,3 \mathrm{~g} / \mathrm{ml}$ merupakan konsentrasi yang baik untuk menghambat tinggi gulma dan panjang akar gulma $A$. spinosus dan $P$. conjugatum (Tabel 3).

\section{Pembahasan \\ Pengaruh Ekstrak Kulit $P$. jiringa Terhadap Persentase Perkecambahan dan Panjang Kecambah Gulma A.spinosus dan P. conjugatum}

Persentase perkecambahan biji gulma A.spinosus dan $P$. conjugatum mengalami penurunan setelah diberi perlakuan dengan ekstrak kulit $P$. jiringa (Tabel 1). Penurunan kemampuan perkecambahan biji gulma A.spinosus dan $P$. conjugatum karena adanya senyawa alelokimia dalam ekstrak kulit $P$. jiringa yang dapat menghambat perkecambahan biji. Berdasarkan hasil penelitian konsentrasi $0,1 \mathrm{~g} / \mathrm{ml}$ merupakan konsentrasi terendah yang mampu menurunkan persentase perkecambahan gulma $A$. spinosus dan $P$. conjugatum sebesar $62 \%$ dan $70 \%$, sedangkan pada konsentrasi $0,5 \mathrm{~g} / \mathrm{ml}$ mampu menurunkan persentase perkecambahan menjadi $4 \%$ dan 8\% (tabel 1). Kondisi ini memperlihatkan bahwa senyawa alelokimia dalam $0,5 \mathrm{~g} / \mathrm{ml}$ ekstrak kulit $P$. jiringa mampu mengendalikan perkecambahan gulma A.spinosus dan $P$. 
conjugatum. Menurut Pradani (2009), senyawa alelokimia yang terdapat pada kulit $P$. jiringa adalah flavonoid, tanin, alkaloid, terpenoid, saponin, dan glikosida.

Menurut Zhao, dkk 2010 flavonoid berperan menghambat proses-proses fisiologi selama perkecambahan sehingga menghambat penyerapan air dan hara, pembelahan sel, respirasi, mengubah aktivitas dan fungsi berbagai enzim, serta menghambat sintesis protein dan hormon tumbuhan seperti asam giberelin (GA). Trenggono (1990) menyatakan bahwa penghambatan sintesis giberelin mengakibatkan tidak akan terjadi induksi enzim $\alpha$ amilase. Enzim $\alpha$-amilase berperan dalam hidrolisis amilum menjadi glukosa pada endosperm di dalam biji sebagai cadangan makanan bagi embrio. Apabila tidak terbentuk enzim $\alpha$-amilase mengakibatkan embrio tidak memiliki sumber energi untuk pertumbuhannya. Senyawa alelokimia kulit $P$. jiringa menghambat perkecambahan gulma $A$. spinosus dan $P$. conjugatum dengan cara mengganggu aktivitas hormon asam giberellin (GA) dan asam indol asetat (IAA). Alelokimia akan menghambat kerja GA sehingga GA tidak dapat mereduksi enzim-enzim perkecambahan seperti $\alpha$ amilase, protease, dan lipase yang akan merombak cadangan makanan pada sel endosperm biji berupa pati dan protein, sehingga energi untuk tumbuh yang dihasilkan selama proses perkecambahan menjadi sedikit dan lambat( Frihartini dkk., 2015).

Ekstrak kulit buah $P$. jiringa selain dapat menurunkan persentase kecambah juga dapat menurunkan panjang kecambah A.spinosus dan P. conjugatum ( Tabel 1). Penghambatan pertumbuhan panjang kecambah terjadi melalui aktivitas senyawa fenol dalam ekstrak kulit buah $P$. jiringa yang menghambat proses mitosis pada embrio sehingga pembelahan sel terhambat sehingga berpengaruh terhadap panjang kecambah. Senyawa terpenoid yang terkandung dalam ekstrak kulit $P$. jiringa dapat menghambat penyusunan mikrotubul sehingga spindel mikrotubul tidak terbentuk dan tidak ada penarikan kromosom ke arah kutub pada saat telofase sehingga jumlah sel tidak bertambah (Wattimena 1987).

\section{Pengaruh ekstrak kulit $\boldsymbol{P}$. jiringa terhadap tinggi gulma, panjang akar, berat basah dan berat kering $A$.spinosus dan $P$. conjugatum}

Hasil penelitian menunjukkan bahwa terdapat pengaruh ekstrak $P$. jiringa terhadap pertumbuhan gulma A. spinosus dan $P$. conjugatum. Tinggi gulma dan panjang akar mengalami penurunan ketika konsentrasi ekstrak dinaikkan hingga $0,5 \mathrm{~g} / \mathrm{ml}$ (Tabel 2). Penghambatan pertumbuhan gulma terjadi karena adanya senyawa alelokimia yang terkandung di dalam kulit $P$. jiringa yang mengganggu aktivitas pembelahan dan pemanjangan sel. Hambatan pembelahan sel oleh senyawa ekstrak $P$. jiringa melalui gangguan aktivitas hormon tumbuhan seperti auksin dan sitokinin yang berperan dalam memacu pembelahan dan pemanjangan sel (Wattimena, 1987).

Perlakuan konsentrasi $0,1 \mathrm{~g} / \mathrm{ml}$ ekstrak kulit buah $P$. jiringa sudah menujukkan hasil yang berbeda nyata pada berat basah dan berat kering gulma $A$. spinosus dan $P$. conjugatum (Tabel 3 ). Senyawa alelokimia yang terdapat di dalam $0,3 \mathrm{~g} / \mathrm{ml}$ ekstrak kulit $P$. jiringa diduga dapat menghambat penguapan dan pengangkutan air oleh gulma sehingga menghambat proses fotosintesis. Menurut Dwijoseputro (1993) berat basah dan berat kering tanaman dipengaruhi oleh kandungan air di dalam sel tanaman dan hasil fotosintesis. Sastroutomo (1990) menyatakan bahwa alelokimia dapat berpengaruh terhadap nilai berat basah dan berat kering tumbuhan yaitu dengan menghambat masuknya air dari media tumbuh ke tubuh tumbuhan. Apabila terjadi gangguan pada pengangkutan air, maka akan menurunkan fungsi sel akar dalam penyerapan ion dari media tanam sehingga pertumbuhan vegetatif tanaman akan terganggu dan menyebabkan penurunan nilai bobot basah dan kering.

Hasil penelitian menggunakan ektrak kulit buah $P$. jiringa pada konsentrasi $0,5 \mathrm{~g} / \mathrm{ml}$ menyebabkan kematian pada gulma (Tabel 2). Riskitavani dan Purwani (2013) menyatakan bahwa semakin tinggi kandungan senyawa alelokimia fenolik seperti tanin, dan flavonoid akan bersifat racun bagi tumbuhan dan menghambat transpor ion terlarut melewati membran sel, sehingga pertumbuhan menjadi terhambat. Jika hal ini berlangsung terusmenerus dapat menyebabkan kematian pada tumbuhan. Berdasarkan hasil penelitian menggunakan ekstrak $P$. jiringa terhadap gulma $A$. spinosus dan $P$. conjugatum dapat dilihat bahwa konsentrasi yang baik yang digunakan untuk mengendalikan perkecambahan gulma $A$. spinosus dan $P$. conjugatum yaitu $0,5 \mathrm{~g} / \mathrm{ml}$, sedangkan konsentrasi ekstrak $P$. jiringa yang baik untuk mengedalikan pertumbuhan gulma $A$. spinosus dan $P$. conjugatum yaitu $0,3 \mathrm{~g} / \mathrm{ml}$. 


\section{DAFTAR PUSTAKA}

Astuti, HS, Sri D, \&Sri H, 2017,'PengaruhAlelokimia Ekstrak Gulma Pilea microphylla terhadap kandungan Superoksida dan Perkecambahan Sawi Hijau (Brassica rapa var. Parachinensis),' Buletin Anatomi dan Fisiologi, vol. 2, no. 1, hal. 8692

Delsi, Y, 2010, 'Viabilitas dan Vigor Gulma yang diberi Beberapa Konsentrasi Ekstrak Kulit Jengkol dan Pengaruhnya Terhadap Tanaman Padi' Skripsi, Fakultas MIPA Universitas Andalas, Padang

Duke, SO \& Lydon, J, 1993, 'Natural phytotoxins as herbicide. Pes control with enhance environmental safety', Amer Chem Soc

Frihantini, N, Linda, R \& Mukarlina, 2015, 'Potensi Ekstrak Daun Bambu Apus (Gigantochla apus Kurz) Sebagai Bioherbisida

Penghambat Perkecambahan Biji dan Pertumbuhan Gulma Rumput Grinting (Cynodon dactylon (L.) Pers)', Protobiont, vol. 4 , no. 2 , hal. $77-83$

Isda, Mayta Novaliza, Siti, F, \& Rahmi, 2013, 'Potensi Ekstrak Daun Gulma Babadotan (Ageratum conyzoides L.) Terhadap Perkecambahan dan Pertumbuhan Paspalum conjugatum Berg.' Al-Kauniyah Jurnal Biologi, vol. 6, no. 2, hal. 121-125

Junaedi, A, Muhammad AC, \& Kwangho K, 2006, Ulasan perkembangan terkini kajian alelopati, Institut Pertanian Bogor, Bogor

Pebriani, Linda, R \& Mukarlina, 2013, 'Potensi Ekstrak Daun Sembung Rambat (Mikania micrantha H.B.K) Sebagai Bioherbisida terhadap Gulma Maman Ungu (Cleome rutidosperma D.C) dan Rumput Bahia (Paspalum notatum Flugge)', Protobiont, vol. 2 , no. 2 hal. $32-38$

Rahayu, E.S. 2001, 'Kulit buah jengkol sebagai herbisida alami pada pertanaman padi sawah', Hasil Pengembangan dan Penerapan Teknologi ( $P \& P T)$, vol. 2, no. 4, hal. 254-260
Riskitavani, Denada Visitia dan Kristanti Indah Purwani. 2013. Studi Potensi Bioherbisida Ekstrak Daun Ketapang(Terminalia catappa) terhadap Gulma Rumput Teki (Cyperus rotundus), Jurnal Sains dan Seni Pomits, vol. 2 , no. 2 , hal. $59-63$

Ronald, AE \& Smith, EC, 2000, The flora of the Nova Scotia, Halif Nova Scotia Museum

Sastroutomo, 1990, Ekologi Gulma, Gramedia Pustaka Utama, Jakarta

Senjaya \& Surakusumah, 2007, 'Potensi Ekstrak Daun Pinus (Pinus merkusii) sebagai Bioherbisida Penghambat Perkecambahan Echinochloa colonum L. dan Amaranthus viridis, Parrenial vol.1, no. 4, hal. 1-5

Trenggono, RM, 1990, Biologi Benih, Institut Pertanian Bogor Press, Bogor

Wattimena, G. A, 1987, Zat Pengatur Tumbuh, PAU Bioteknologi IPB, Bogor 